\title{
Dokdonia donghaensis gen. nov., sp. nov., isolated from sea water
}

Correspondence

Jung-Hoon Yoon

jhyoon@kribb.re.kr

Tae-Kwang Oh

otk@kribb.re.kr

\author{
Jung-Hoon Yoon, So-Jung Kang, Choong-Hwan Lee and Tae-Kwang Oh \\ Korea Research Institute of Bioscience and Biotechnology (KRIBB), PO Box 115, Yusong, \\ Taejon, South Korea
}

Two Gram-negative, non-motile, non-spore-forming, slightly halophilic bacterial strains, DSW-1 ${ }^{\top}$ and DSW-21, were isolated from sea water and subjected to a polyphasic taxonomic study. They grew optimally at $30{ }^{\circ} \mathrm{C}$ and in the presence of $2 \%(\mathrm{w} / \mathrm{v}) \mathrm{NaCl}$. Strains DSW $-1^{\top}$ and DSW-21 were characterized chemotaxonomically as containing MK-6 as the predominant menaquinone and iso- $\mathrm{C}_{15: 0}$, iso- $\mathrm{C}_{17: 0} 3-\mathrm{OH}$ and iso- $\mathrm{C}_{15: 1}$ as the major fatty acids. Their DNA G+C content was $38 \mathrm{~mol} \%$. Strains DSW-1 ${ }^{\top}$ and DSW-21 exhibited four nucleotide differences in their $16 \mathrm{~S}$ rRNA gene sequences and possessed a mean DNA-DNA relatedness level of $78 \%$. Phylogenetic analyses based on $16 \mathrm{~S}$ rRNA gene sequences revealed that strains DSW-1 ${ }^{\top}$ and DSW-21 formed a distinct lineage within the family Flavobacteriaceae. The 16S rRNA gene sequences of strains DSW-1 ${ }^{\top}$ and DSW-21 had similarity levels of less than $92 \cdot 2 \%$ to the sequences of other members of the family Flavobacteriaceae. There were some differences in phenotypic properties between the two strains and Cellulophaga species, the nearest phylogenetic neighbours. On the basis of phenotypic, phylogenetic and genetic data, strains DSW-1 ${ }^{\top}$ $\left(=\right.$ KCTC $12391^{\top}=$ DSM $\left.17200^{\top}\right)$ and DSW-21 were classified in a novel genus and species,

Dokdonia donghaensis gen. nov., sp. nov.
Members of the Cytophaga-Flavobacterium-Bacteroides (CFB) group constitute one of the bacterial groups that exist dominantly in marine environments (Bowman et al., 1997; Glöckner et al., 1999; Kirchman, 2002). The CFB group is well known to be proficient in degrading biopolymers, such as cellulose and chitin (Kirchman, 2002). During the last few years, the number of novel genera assigned to the CFB group, including the recently described genera Winogradskyella (Nedashkovskaya et al., 2005a), Pibocella (Nedashkovskaya et al., 2005b), Aquimarina and Stanierella (Nedashkovskaya et al., 2005c), Roseivirga (Nedashkovskaya et al., 2005d), Bizionia (Nedashkovskaya et al., 2005e), Gramella (Nedashkovskaya et al., 2005f), Sejongia (Yi et al., 2005) and Marinicola (Yoon et al., 2005), has increased continuously. In this study, we describe two Gram-negative, slightly halophilic bacterial strains, DSW $-1^{\mathrm{T}}$ and DSW-21, which were isolated from sea water around a Korean island, Dokdo. The result of $16 \mathrm{~S}$ rRNA gene sequence comparison indicated that the two strains are

Published online ahead of print on 22 July 2005 as DOI 10.1099/ ijs.0.63817-0.

The GenBank/EMBL/DDBJ accession numbers for the 16S rRNA gene sequences of strains DSW-1 ${ }^{\top}$ and DSW-21 are D0003276 and DQ003277, respectively.

A table showing the cellular fatty acid composition of Dokdonia donghaensis gen. nov., sp. nov. and Cellulophaga species is available as supplementary material in IJSEM Online. phylogenetically affiliated to the CFB group. Accordingly, the aim of the present work was to investigate the taxonomic status of strains DSW $-1^{\mathrm{T}}$ and DSW-21 by a polyphasic taxonomic characterization.

Sea water collected from Dokdo was used as source for the isolation of bacterial strains. Strains DSW $-1^{\mathrm{T}}$ and DSW-21 were isolated by the standard dilution plating technique on marine agar 2216 (MA; Difco) at $25^{\circ} \mathrm{C}$. Cell morphology was examined by light microscopy (Nikon E600) and transmission electron microscopy. The presence of flagella was determined by transmission electron microscopy using cells from exponentially growing cultures. Gliding motility was investigated as described by Bowman (2000). The Gram reaction was determined by using the bioMérieux Gram Stain kit according to the manufacturer's instructions. The $\mathrm{pH}$ range for growth was determined in marine broth 2216 (MB; Difco) that was adjusted to various $\mathrm{pH}$ values (initial $\mathrm{pH} 4 \cdot 5-10 \cdot 5$ at intervals of $0 \cdot 5 \mathrm{pH}$ units). The $\mathrm{pH}$ was adjusted prior to sterilization to various levels by the addition of $\mathrm{HCl}$ or $\mathrm{Na}_{2} \mathrm{CO}_{3}$. Growth in the absence of $\mathrm{NaCl}$ was investigated in trypticase soy broth prepared according to the formula of the Difco medium except that no $\mathrm{NaCl}$ was used. Growth at various $\mathrm{NaCl}$ concentrations $[0 \cdot 5 \%(\mathrm{w} / \mathrm{v})$ and $1 \cdot 0-10 \cdot 0 \%(\mathrm{w} / \mathrm{v})$ at intervals of $1 \cdot 0 \%$ units] was investigated in $\mathrm{MB}$ or trypticase soy broth. Growth at various temperatures $\left(4-40^{\circ} \mathrm{C}\right)$ was measured on MA. Growth under anaerobic conditions was determined after incubation in an anaerobic chamber on MA 
and on MA supplemented with nitrate, both of which had been prepared anaerobically using nitrogen. Catalase and oxidase activities and hydrolysis of casein and starch were determined as described by Cowan \& Steel (1965). Hydrolysis of Tweens 20, 40, 60 and 80 was determined as described by Cowan \& Steel (1965) with a modification that artificial sea water was used instead of distilled water. Hydrolysis of aesculin, gelatin and urea and nitrate reduction were determined as described by Lanyi (1987) with a modification that artificial sea water was used instead of distilled water. The artificial sea water contained (per litre of distilled water) $23.6 \mathrm{~g} \mathrm{NaCl}, 0.64 \mathrm{~g} \mathrm{KCl}, 4.53 \mathrm{~g}$ $\mathrm{MgCl}_{2} \cdot 6 \mathrm{H}_{2} \mathrm{O}, 5 \cdot 94 \mathrm{~g} \mathrm{MgSO}_{4} .7 \mathrm{H}_{2} \mathrm{O}$ and $1.3 \mathrm{~g} \mathrm{CaCl}_{2} \cdot 2 \mathrm{H}_{2} \mathrm{O}$ (Bruns et al., 2001). Hydrolysis of hypoxanthine, tyrosine and xanthine was investigated on MA with the substrate concentrations described by Cowan \& Steel (1965). The production of $\mathrm{H}_{2} \mathrm{~S}$ was tested as described previously (Bruns et al., 2001). Presence of flexirubin-type pigments was investigated as described by Reichenbach (1992). Freeze-dried cells were extracted with acetone/methanol $(1: 1, \mathrm{v} / \mathrm{v})$ to investigate the presence of carotenoids. Acid production from carbohydrates was determined as described by Leifson (1963). Growth on several substrates was tested in a basal medium containing $0.2 \mathrm{~g} \mathrm{NaNO}_{3}$, $0 \cdot 2 \mathrm{~g} \mathrm{NH}_{4} \mathrm{Cl}$ and $0.05 \mathrm{~g}$ yeast extract in $1000 \mathrm{ml}$ artificial sea water (Bruns et al., 2001) as described by Suzuki et al. (2001). Enzyme activity was determined by using the API ZYM system (bioMérieux). Susceptibility to antibiotics was tested on MA plates using antibiotic discs containing the following concentrations: polymyxin B, $100 \mathrm{U}$; streptomycin, $50 \mu \mathrm{g}$; penicillin $\mathrm{G}, 20 \mathrm{U}$; chloramphenicol, $100 \mu \mathrm{g}$; ampicillin, $10 \mu \mathrm{g}$; cephalothin, $30 \mu \mathrm{g}$; gentamicin, $30 \mu \mathrm{g}$; novobiocin, $5 \mu \mathrm{g}$; tetracycline, $30 \mu \mathrm{g}$; kanamycin, $30 \mu \mathrm{g}$; lincomycin, $15 \mu \mathrm{g}$; oleandomycin, $15 \mu \mathrm{g}$; neomycin, $30 \mu \mathrm{g}$; carbenicillin, $100 \mu \mathrm{g}$. Other physiological and biochemical tests were performed using the API $20 \mathrm{E}$ system (bioMérieux).

Cell biomass of strains DSW-1 ${ }^{\mathrm{T}}$ and DSW-21 for DNA extraction and for isoprenoid quinone and polar lipid analyses was obtained by cultivation for 2 days in $\mathrm{MB}$ at $30{ }^{\circ} \mathrm{C}$. Chromosomal DNA was isolated and purified according to the method described previously (Yoon et al., 1996), with the exception that ribonuclease T1 was used in combination with ribonuclease A to minimize contamination with RNA. The 16S rRNA gene was amplified by PCR using two universal primers as described previously (Yoon et al., 1998). Sequencing of the amplified $16 \mathrm{~S}$ rRNA gene and phylogenetic analysis were performed as described by Yoon et al. (2003). The DNA G + C content was determined by the method of Tamaoka \& Komagata (1984) with a modification that DNA was hydrolysed and the resultant nucleotides were analysed by reversed-phase HPLC. DNA-DNA hybridization was performed fluorometrically by the method of Ezaki et al. (1989) using photobiotin-labelled DNA probes and microdilution wells. Hybridization was performed with five replicates for each sample. The highest and lowest values obtained in each sample were excluded, and the means of the remaining three values were quoted as DNA-DNA relatedness values. Isoprenoid quinones were extracted according to the method of Komagata \& Suzuki (1987) and analysed using reversed-phase HPLC and a YMC ODS-A $(250 \times 4.6 \mathrm{~mm})$ column. Polar lipids were extracted according to the procedures described by Minnikin et al. (1984) and identified by two-dimensional TLC followed by spraying with appropriate detection reagents (Minnikin et al., 1984; Komagata \& Suzuki, 1987). For fatty acid methyl ester analysis, cell mass of strains DSW $-1^{\mathrm{T}}$ and DSW-21 was harvested from agar plates after incubation for 3 days on $\mathrm{MA}$ at $30^{\circ} \mathrm{C}$. The fatty acid methyl esters were extracted and prepared according to the standard protocol of the MIDI/ Hewlett Packard Microbial Identification System (Sasser, 1990).

Morphological, cultural, physiological and biochemical characteristics of strains DSW $-1^{\mathrm{T}}$ and DSW-21 are given in the genus and species descriptions (see below) or are shown in Table 1, together with those of Cellulophaga species. Strains DSW- $1^{\mathrm{T}}$ and DSW-21 produced carotenoid pigments (absorption maxima at 453 and $477-478 \mathrm{~nm}$ ) but no flexirubin-type pigments. The two strains produced no acid from the substrates used in this study. The predominant isoprenoid quinone found in strains DSW $-1^{\mathrm{T}}$ and DSW-21 was menaquinone-6 (MK-6) at a peak area ratio of approximately $96-97 \%$. Strains $D S W-1^{\mathrm{T}}$ and DSW-21 had cellular fatty acid profiles that contained large amounts of branched, hydroxy and straight-chain fatty acids; the major components ( $>5 \%$ of total fatty acids) were iso- $\mathrm{C}_{15: 0}(26 \cdot 0$ and $25 \cdot 6 \%)$, iso- $\mathrm{C}_{17: 0} 3-\mathrm{OH}(15 \cdot 2$ and $16 \cdot 4 \%)$, iso- $\mathrm{C}_{15: 1}(13.6$ and $13 \cdot 3 \%)$, summed feature 3 (i.e. $\mathrm{C}_{16: 1} \omega 7 c$ and/or iso- $\left.\mathrm{C}_{15: 0} 2-\mathrm{OH}\right)(7 \cdot 5$ and $7 \cdot 9 \%)$, iso- $\mathrm{C}_{16: 0} 3-\mathrm{OH}(7 \cdot 2$ and $9 \cdot 2 \%)$ and anteiso- $\mathrm{C}_{15: 0}(4 \cdot 5$ and $5.5 \%$ ) (supplementary table in IJSEM Online). Phosphatidylethanolamine was the only phospholipid identified in strains DSW-1 ${ }^{\mathrm{T}}$ and DSW-21, and other major polar lipids were two unidentified phospholipids, an unidentified glycolipid and an amino-group-containing lipid that was ninhydrin-positive.

Almost complete 16S rRNA gene sequences of strains DSW $-1^{\mathrm{T}}$ and DSW-21 determined in this study comprised 1479 nucleotides, representing approximately $96 \%$ of the Escherichia coli sequence. There were four nucleotide differences between the 16S rRNA gene sequences of the two strains. Phylogenetic trees based on 16S rRNA gene sequences showed that strains DSW $-1^{\mathrm{T}}$ and DSW-21 formed a distinct lineage of descent within the family Flavobacteriaceae (Fig. 1). In the phylogenetic tree based on the neighbour-joining algorithm, strains DSW- $1^{\mathrm{T}}$ and DSW-21 joined the phylogenetic clade comprising Cellulophaga species. The two strains exhibited 16S rRNA gene sequence similarity values of $90 \cdot 4-92 \cdot 2 \%$ with respect to the type strains of recognized Cellulophaga species and of less than $91.7 \%$ with respect to the other species used in the phylogenetic analysis (Fig. 1). The DNA G $+\mathrm{C}$ content of strains DSW $-1^{\mathrm{T}}$ and DSW-21 was $38 \cdot 3 \mathrm{~mol} \%$. The 
Table 1. Differential phenotypic characteristics of Dokdonia donghaensis gen. nov., sp. nov. and Cellulophaga species

Species: 1, Dokdonia donghaensis gen. nov., sp. nov.; 2, Cellulophaga baltica, data from Johansen et al. (1999), Bowman (2000) and Nedashkovskaya et al. (2004); 3, Cellulophaga fucicola, data from Johansen et al. (1999), Bowman (2000) and Nedashkovskaya et al. (2004); 4, Cellulophaga lytica, data from Johansen et al. (1999), Bowman (2000) and Nedashkovskaya et al. (2004); 5, Cellulophaga algicola, data from Bowman (2000) and Nedashkovskaya et al. (2004); 6, Cellulophaga pacifica, data from Nedashkovskaya et al. (2004). +, Positive reaction; -, negative reaction; ND, not determined; v, variable reaction. Data in parentheses are for the type strain. All species are positive for catalase, $\mathrm{NaCl}$ requirement for growth and growth at $6 \% \mathrm{NaCl}$. All species are negative for anaerobic growth and production of flexirubin-type pigments.

\begin{tabular}{|c|c|c|c|c|c|c|}
\hline Characteristic & 1 & 2 & 3 & 4 & 5 & 6 \\
\hline Oxidase & + & $-{ }^{*}$ & $-*$ & + & + & + \\
\hline Gliding motility & - & + & + & + & + & + \\
\hline Nitrate reduction & - & $(-)^{*}$ & $+^{*}$ & - & + & + \\
\hline Urease & - & $(-)$ & + & - & - & ND \\
\hline \multicolumn{7}{|l|}{ Growth at: } \\
\hline $8 \%(\mathrm{w} / \mathrm{v}) \mathrm{NaCl}$ & - & - & - & $+\dagger$ & $+\dagger$ & $\mathrm{V}(-)$ \\
\hline $4^{\circ} \mathrm{C}$ & + & + & + & $-\dagger$ & + & + \\
\hline $37^{\circ} \mathrm{C}$ & - & - & - & $(+)$ & - & - \\
\hline \multicolumn{7}{|l|}{ Hydrolysis of: } \\
\hline Agar & - & + & + & + & + & + \\
\hline Casein & + & + & - & $\mathrm{V}(-)$ & $+\dagger$ & - \\
\hline Gelatin & - & + & $-\ddagger$ & $\mathrm{V}(+)$ & + & + \\
\hline Starch & - & + & + & + & + & + \\
\hline L-Tyrosine & - & + & + & + & + & ND \\
\hline Tween 20 & + & $(+)$ & + & $(+)$ & $(-)$ & + \\
\hline Tween 40 & + & $(-)$ & + & $(+)$ & $(+)$ & + \\
\hline Tween 80 & + & $(+)$ & + & $\mathrm{V}(-)$ & $+\dagger$ & $\mathrm{V}(+)$ \\
\hline \multicolumn{7}{|l|}{ Acid production from: } \\
\hline L-Arabinose & - & $(-)$ & $+^{*}$ & $\mathrm{~V}(-)$ & - & + \\
\hline D-Cellobiose & - & $(+)^{*}$ & + & + & $+\dagger$ & + \\
\hline D-Fructose & - & $(+)$ & + & + & $\mathrm{V}(-)$ & ND \\
\hline D-Galactose & - & $(+)^{*}$ & $+^{*}$ & + & $+\dagger$ & + \\
\hline D-Glucose & - & $(+)^{*}$ & + & + & + & + \\
\hline Lactose & - & $(-)$ & - & + & + & + \\
\hline Maltose & - & $(-)^{*}$ & - & + & + & + \\
\hline D-Mannose & - & $(+)$ & - & + & + & ND \\
\hline Melibiose & - & $(-)$ & - & $(-)$ & $(+)$ & - \\
\hline D-Raffinose & - & $(-)$ & - & $(-)$ & $(-)$ & + \\
\hline Sucrose & - & $(+)$ & $+^{*}$ & $+\dagger$ & $+\dagger$ & + \\
\hline D-Xylose & - & $(+)^{*}$ & - & $\mathrm{v}(-\dagger)$ & - & $\mathrm{V}(+)$ \\
\hline D-Mannitol & - & $(-)^{*}$ & - & $+\dagger$ & - & - \\
\hline L-Rhamnose & - & $(-)$ & $+^{*}$ & $\mathrm{~V}(-)$ & - & - \\
\hline \multicolumn{7}{|l|}{ Susceptibility to antibiotics } \\
\hline Ampicillin $(10 \mu \mathrm{g}$ per disc $)$ & - & $(-)$ & - & $(-)$ & $(-)$ & $\mathrm{V}(-)$ \\
\hline Carbenicillin & + & $(-)$ & - & $(-)$ & $(-)$ & + \\
\hline Streptomycin & - & $(-)$ & - & $(-)$ & $(-)$ & $\mathrm{V}(+)$ \\
\hline Tetracycline $(30 \mu \mathrm{g}$ per disc $)$ & + & $(-)$ & - & $(-)$ & $(+)$ & - \\
\hline DNA G $+\mathrm{C}$ mol $\% \$$ & 38 & $(33-35)^{*}$ & $32-34$ & $32-34$ & $33-38$ & $32-34$ \\
\hline
\end{tabular}

${ }^{\star}$ Data taken from Johansen et al. (1999) and/or Bowman (2000); the opposite result was reported by Nedashkovskaya et al. (2004).

$\dagger$ Data taken from Bowman (2000); the opposite result for the type strain was reported by Nedashkovskaya et al. (2004). ¥Data taken from Johansen et al. (1999); the opposite result was reported by Bowman (2000) and Nedashkovskaya et al. (2004).

$\S$ Data ( $T_{\mathrm{m}}$ and HPLC data) taken from Johansen et al. (1999), Bowman (2000) and Nedashkovskaya et al. (2004). 


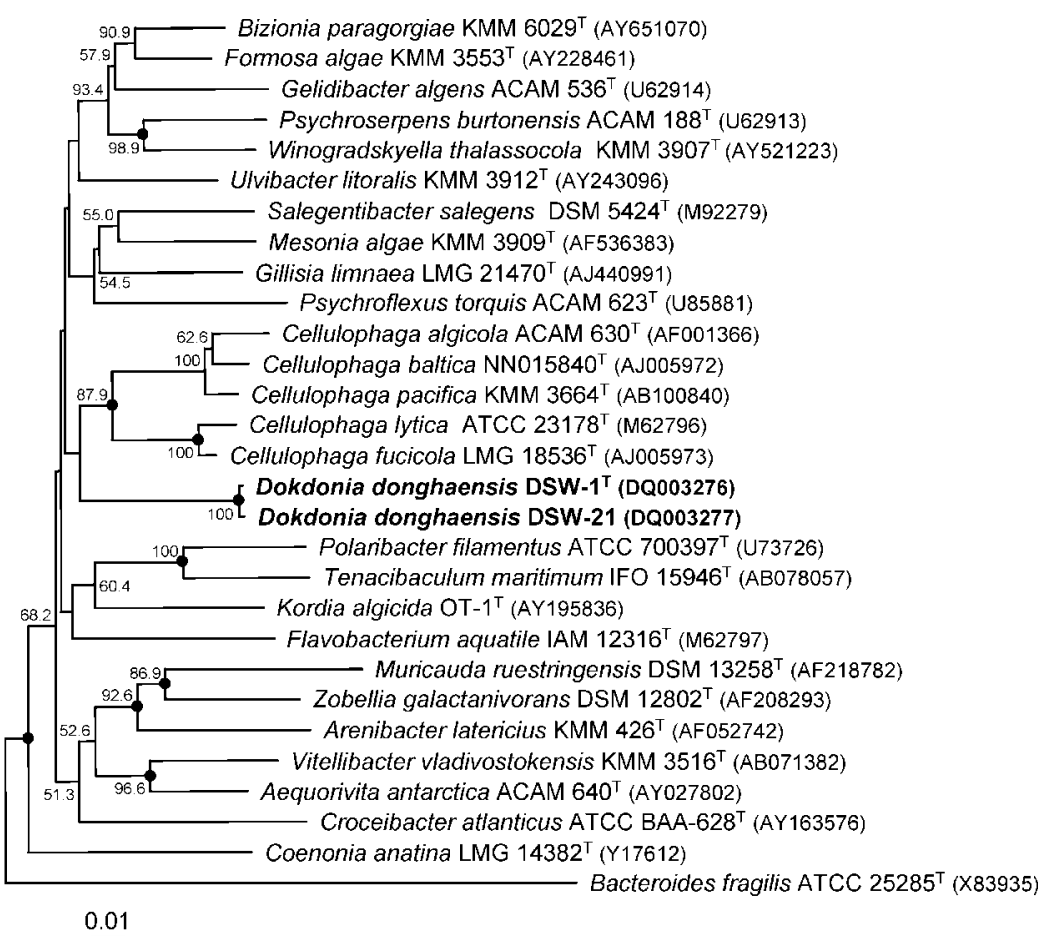

Fig. 1. Neighbour-joining tree based on 16S rRNA gene sequences showing the phylogenetic positions of strains $\mathrm{DSW}-1^{\top}$ and DSW-21 and representatives of some other related taxa. Bootstrap values (expressed as percentages of 1000 replications) greater than $50 \%$ are shown at the branch points. Bacteroides fragilis ATCC $25285^{\top}$ was used as an outgroup. Dots indicate that the corresponding nodes were also recovered in the tree generated with the maximum-likelihood algorithm. Scale bar, 0.01 substitutions per nucleotide position. mean DNA-DNA relatedness value of strains DSW $-1^{\mathrm{T}}$ and DSW-21 was $78 \%$, when their DNAs were used individually as labelled DNA probes for cross-hybridization, indicating that the two strains were members of the same genomic species (Wayne et al., 1987). In view of the combined phenotypic, phylogenetic and genetic similarity, strains DSW $-1^{\mathrm{T}}$ and DSW-21 could be considered as members of the same species.

The two strains contained the same predominant menaquinone type (MK-6) as members of the genus Cellulophaga and the other members of the family Flavobacteriaceae (Bernardet et al., 2002). They also shared the same major cellular fatty acids (iso- $\mathrm{C}_{15: 0}$, iso- $\mathrm{C}_{17: 0} 3-\mathrm{OH}$ and iso$\mathrm{C}_{15: 1}$ ) with the Cellulophaga species (Bowman, 2000; Nedashkovskaya et al., 2004; supplementary table in IJSEM Online), although differences in the relative proportions of some fatty acids (e.g. $\mathrm{C}_{15: 0}$, iso- $\mathrm{C}_{15: 0}$ and $\mathrm{C}_{16: 1} \omega 7 c$ ) were noticed. These differences might partly be caused by different cultivation conditions. Strains DSW $-1^{\mathrm{T}}$ and DSW21 were differentiated from Cellulophaga species in some phenotypic properties, including gliding motility, acid production from carbohydrates and hydrolysis of some substrates (Table 1). The result of 16S rRNA gene sequence analyses and differential phenotypic properties were sufficient to categorize strains DSW $-1^{\mathrm{T}}$ and DSW-21 as members of a genus that is separate from the recognized genera of the family Flavobacteriaceae. Therefore, on the basis of the data presented, strains DSW $-1^{\mathrm{T}}$ and DSW-21 should be classified as members of a novel genus and species, for which the name Dokdonia donghaensis gen. nov., sp. nov. is proposed.

\section{Description of Dokdonia gen. nov.}

Dokdonia (Dok.do'ni.a. N.L. fem. n. Dokdonia named after Dokdo, an island located on the East Sea in Korea, from where the organisms were isolated).

Cells are Gram-negative, non-spore-forming rods or elongated rods. Strictly aerobic. Non-motile. Catalaseand oxidase-positive. The predominant menaquinone is MK-6. The type species is Dokdonia donghaensis.

\section{Description of Dokdonia donghaensis sp. nov.}

Dokdonia donghaensis (dong.ha.en'sis. N.L. fem. adj. donghaensis of Donghae, the Korean name of the East Sea of Korea, where Dokdo is located and from where the organism was isolated).

Exhibits the following properties in addition to those given in the genus description. Cells are $0 \cdot 3-0 \cdot 6 \times 1 \cdot 5-25 \cdot 0 \mu \mathrm{m}$. Colonies on marine agar 2216 (MA) are circular, slightly convex, glistening, smooth, yellow in colour and $1 \cdot 0-2 \cdot 0 \mathrm{~mm}$ in diameter after incubation for 3 days at $30{ }^{\circ} \mathrm{C}$. Growth occurs at 4 and $35^{\circ} \mathrm{C}$ with an optimum temperature of $30^{\circ} \mathrm{C}$; growth does not occur at $36^{\circ} \mathrm{C}$. Optimal $\mathrm{pH}$ for growth is $7 \cdot 0-8 \cdot 0$; growth is observed at $\mathrm{pH} 5 \cdot 5$, but not at $\mathrm{pH} 5 \cdot 0$. Optimal growth occurs in the presence of $2 \%(\mathrm{w} / \mathrm{v}) \mathrm{NaCl}$; growth does not occur in the absence of $\mathrm{NaCl}$ and in the presence of greater than $7 \%(\mathrm{w} / \mathrm{v})$ $\mathrm{NaCl}$. Anaerobic growth does not occur on MA and on MA supplemented with nitrate. Aesculin and Tween 60 are hydrolysed, but hypoxanthine and xanthine are not. Indole and $\mathrm{H}_{2} \mathrm{~S}$ are not produced. Arginine dihydrolase, lysine 
decarboxylase, ornithine decarboxylase and tryptophan deaminase are absent. In assays with the API ZYM system, alkaline phosphatase, esterase (C4), esterase lipase (C8), leucine arylamidase and valine arylamidase are present, but lipase (C14), cystine arylamidase, trypsin, $\alpha$-chymotrypsin, acid phosphatase, naphthol-AS-BI-phosphohydrolase, $\alpha$ galactosidase, $\beta$-galactosidase, $\beta$-glucuronidase, $\alpha$-glucosidase, $\beta$-glucosidase, $N$-acetyl- $\beta$-glucosaminidase, $\alpha$-mannosidase and $\alpha$-fucosidase are absent. Susceptible to penicillin G, chloramphenicol, cephalothin, lincomycin and oleandomycin, but not to polymyxin B, gentamicin, novobiocin, kanamycin or neomycin. Growth occurs on peptone and tryptone as the sole carbon and nitrogen sources, but not on D-glucose, sucrose, D-ribose, D-galactose, D-fructose, Dcellobiose, D-trehalose, Casamino acids, DL-aspartate, Lglutamate, L-leucine or L-proline. Acid is not produced from D-ribose, D-trehalose, D-sorbitol or myo-inositol. The major fatty acids ( $>10 \%$ of total fatty acids) are iso- $\mathrm{C}_{15: 0}$, iso- $\mathrm{C}_{17: 0} 3-\mathrm{OH}$ and iso- $\mathrm{C}_{15: 1}$. The major polar lipids are phosphatidylethanolamine, unidentified phospholipids, an unidentified glycolipid and an amino-group-containing lipid that is ninhydrin-positive. The DNA G $+\mathrm{C}$ content is $38 \mathrm{~mol} \%$. Other phenotypic properties are given in Table 1.

The type strain, DSW $-1^{\mathrm{T}}\left(=\mathrm{KCTC} 12391^{\mathrm{T}}=\mathrm{DSM} 17200^{\mathrm{T}}\right)$, was isolated from sea water. Another reference strain is DSW-21.

\section{Acknowledgements}

This work was supported by the 21C Frontier program of Microbial Genomics and Applications (grant MG02-0401-001-1-0-0) from the Ministry of Science and Technology (MOST) of the Republic of Korea. We are grateful to the Cultural Heritage Administration and the Gyeongsangbuk-do Administration of the Republic of Korea for aiding access to Dokdo.

\section{References}

Bernardet, J.-F., Nakagawa, Y. \& Holmes, B. (2002). Proposed minimal standards for describing new taxa of the family Flavobacteriaceae and emended description of the family. Int J Syst Evol Microbiol 52, 1049-1070.

Bowman, J. P. (2000). Description of Cellulophaga algicola sp. nov., isolated from the surfaces of Antarctic algae, and reclassification of Cytophaga uliginosa (ZoBell and Upham 1944) Reichenbach 1989 as Cellulophaga uliginosa comb. nov. Int J Syst Evol Microbiol 50, 1861-1868.

Bowman, J. P., McCammon, S. A., Brown, M. V., Nichols, D. S. \& McMeekin, T. A. (1997). Diversity and association of psychrophilic bacteria in Antarctic sea ice. Appl Environ Microbiol 63, 3068-3078.

Bruns, A., Rohde, M. \& Berthe-Corti, L. (2001). Muricauda ruestringensis gen. nov., sp. nov., a facultatively anaerobic, appendaged bacterium from German North Sea intertidal sediment. Int J Syst Evol Microbiol 51, 1997-2006.

Cowan, S. T. \& Steel, K. J. (1965). Manual for the Identification of Medical Bacteria. London: Cambridge University Press.

Ezaki, T., Hashimoto, Y. \& Yabuuchi, E. (1989). Fluorometric deoxyribonucleic acid-deoxyribonucleic acid hybridization in microdilution wells as an alternative to membrane filter hybridization in which radioisotopes are used to determine genetic relatedness among bacterial strains. Int J Syst Bacteriol 39, 224-229.

Glöckner, F. O., Fuchs, B. M. \& Amann, R. (1999). Bacterioplankton compositions of lakes and oceans: a first comparison based on fluorescence in situ hybridization. Appl Environ Microbiol 65, 3721-3726.

Johansen, J. E., Nielsen, P. \& Sjøholm, C. (1999). Description of Cellulophaga baltica gen. nov., sp. nov. and Cellulophaga fucicola gen. nov., sp. nov. and reclassification of [Cytophaga] lytica to Cellulophaga lytica gen. nov., comb. nov. Int J Syst Bacteriol 49, 1231-1240.

Kirchman, D. L. (2002). The ecology of Cytophaga-Flavobacteria in aquatic environments. FEMS Microbiol Ecol 39, 91-100.

Komagata, K. \& Suzuki, K. (1987). Lipids and cell-wall analysis in bacterial systematics. Methods Microbiol 19, 161-203.

Lanyi, B. (1987). Classical and rapid identification methods for medically important bacteria. Methods Microbiol 19, 1-67.

Leifson, E. (1963). Determination of carbohydrate metabolism of marine bacteria. J Bacteriol 85, 1183-1184.

Minnikin, D. E., O'Donnell, A. G., Goodfellow, M., Alderson, G., Athalye, M., Schaal, A. \& Parlett, J. H. (1984). An integrated procedure for the extraction of bacterial isoprenoid quinones and polar lipids. J Microbiol Methods 2, 233-241.

Nedashkovskaya, O. I., Suzuki, M., Lysenko, A. M., Snauwaert, C., Vancanneyt, M., Swings, J., Vysotskii, M. \& Mikhailov, V. V. (2004). Cellulophaga pacifica sp. nov. Int J Syst Evol Microbiol 54, 609-613.

Nedashkovskaya, O. I., Kim, S. B., Han, S. K. \& 9 other authors (2005a). Winogradskyella thalassocola gen. nov., sp. nov., Winogradskyella epiphytica sp. nov. and Winogradskyella eximia sp. nov., marine bacteria of the family Flavobacteriaceae. Int J Syst Evol Microbiol 55, 49-55.

Nedashkovskaya, O. I., Kim, S. B., Lee, K. H., Bae, K. S., Frolova, G. M., Mikhailov, V. V. \& Kim, I. S. (2005b). Pibocella ponti gen. nov., sp. nov., a novel marine bacterium of the family Flavobacteriaceae isolated from the green alga Acrosiphonia sonderi. Int J Syst Evol Microbiol 55, 177-181.

Nedashkovskaya, O. I., Kim, S. B., Lysenko, A. M., Frolova, G. M., Mikhailov, V. V., Lee, K. H. \& Bae, K. S. (2005c). Description of Aquimarina muelleri gen. nov., sp. nov., and proposal of the reclassification of [Cytophaga] latercula Lewin 1969 as Stanierella latercula gen. nov., comb. nov. Int J Syst Evol Microbiol 55, 225-229.

Nedashkovskaya, O. I., Kim, S. B., Lee, D. H., Lysenko, A. M., Shevchenko, L. S., Frolova, G. M., Mikhailov, V. V., Lee, K. H. \& Bae, K. S. (2005d). Roseivirga ehrenbergii gen. nov., sp. nov., a novel marine bacterium of the phylum 'Bacteroidetes', isolated from the green alga Ulva fenestrata. Int J Syst Evol Microbiol 55, 231-234.

Nedashkovskaya, O. I., Kim, S. B., Lysenko, A. M., Frolova, G. M., Mikhailov, V. V. \& Bae, K. S. (2005e). Bizionia paragorgiae gen. nov., sp. nov., a novel member of the family Flavobacteriaceae isolated from the soft coral Paragorgia arborea. Int J Syst Evol Microbiol 55, 375-378.

Nedashkovskaya, O. I., Kim, S. B., Lysenko, A. M., Frolova, G. M., Mikhailov, V. V., Bae, K. S., Lee, D. H. \& Kim, I. S. (2005f). Gramella echinicola gen. nov., sp. nov., a novel halophilic bacterium of the family Flavobacteriaceae isolated from the sea urchin Strongylocentrotus intermedius. Int J Syst Evol Microbiol 55, 391-394.

Reichenbach, H. (1992). The order Cytophagales. In the Prokaryotes. A Handbook on the Biology of Bacteria: Ecophysiology, Isolation, Identification, Applications, 2nd edn, pp. 3631-3675. Edited by A. Balows, H. G. Trüper, M. Dworkin, W. Harder \& K. H. Schleifer. New York: Springer. 
Sasser, M. (1990). Identification of Bacteria by Gas Chromatography of Cellular Fatty Acids. Newark, DE: MIDI.

Suzuki, M., Nakagawa, Y., Harayama, S. \& Yamamoto, S. (2001). Phylogenetic analysis and taxonomic study of marine Cytophaga-like bacteria: proposal for Tenacibaculum gen. nov. with Tenacibaculum maritimum comb. nov. and Tenacibaculum ovolyticum comb. nov., and description of Tenacibaculum mesophilum sp. nov. and Tenacibaculum amylolyticum sp. nov. Int J Syst Evol Microbiol 51, 1639-1652.

Tamaoka, J. \& Komagata, K. (1984). Determination of DNA base composition by reverse-phase high-performance liquid chromatography. FEMS Microbiol Lett 25, 125-128.

Wayne, L. G., Brenner, D. J., Colwell, R. R. \& 9 other authors (1987). International Committee on Systematic Bacteriology. Report of the ad hoc committee on reconciliation of approaches to bacterial systematics. Int J Syst Bacteriol 37, 463-464.
Yi, H., Yoon, H. I. \& Chun, J. (2005). Sejongia antarctica gen. nov., sp. nov. and Sejongia jeonii sp. nov., isolated from the Antarctic. Int J Syst Evol Microbiol 55, 409-416.

Yoon, J.-H., Kim, H., Kim, S.-B., Kim, H.-J., Kim, W. Y., Lee, S. T., Goodfellow, M. \& Park, Y.-H. (1996). Identification of Saccharomonospora strains by the use of genomic DNA fragments and rRNA gene probes. Int J Syst Bacteriol 46, 502-505.

Yoon, J.-H., Lee, S. T. \& Park, Y.-H. (1998). Inter- and intraspecific phylogenetic analysis of the genus Nocardioides and related taxa based on 16S rRNA gene sequences. Int J Syst Bacteriol 48, 187-194.

Yoon, J.-H., Kang, K. H. \& Park, Y.-H. (2003). Psychrobacter jeotgali sp. nov., isolated from jeotgal, a traditional Korean fermented seafood. Int J Syst Evol Microbiol 53, 449-454.

Yoon, J.-H., Kang, S.-J., Lee, C.-H. \& Oh, T.-K. (2005). Marinicola seohaensis gen. nov., sp. nov., isolated from sea water of the Yellow Sea, Korea. Int J Syst Evol Microbiol 55, 859-863. 